\title{
PERAN KELUARGA DAN PASIEN DALAM MENINGKATKAN \\ KESELAMATAN DAN PENCEGAHAN COVID 19
}

\author{
Hanita Grace Sagala \\ Email : hanitagrace10@gmail.com
}

\begin{abstract}
ABSTRAK
Pada awal tahun 2020 ini dunia dikejutkan dengan wabah virus corona (Covid-19) yang menginfeksi hampir seluruh negara di dunia. WHO Semenjak Januari 2020 telah menyatakan dunia masuk kedalam darurat global terkait virus ini2. Ini merupakan fenomena luar biasa yang terjadi di bumi pada abad ke 21. Keluarga sebagai unit terkecil dalam masyarakat yang terdiri dari suami istri, atau suami, istri dan anaknya, atau ayah dan anaknya, atau ibu dan anaknya, tentu memiliki peran penting dalam meningkatkan keselamatan dan mencegah penyakit yang disebabkan oleh Corona Virus Disease 2019 (Covid-19).
\end{abstract}

Kata kuci : covid-19, keluarga, pencegahan

\section{LATAR BELAKANG}

Pada Desember 2019, kasus pneumonia misterius pertama kali dilaporkan di Wuhan, Provinsi Hubei. Sumber penularan kasus ini masih belum diketahui pasti, tetapi kasus pertama dikaitkan dengan pasar ikan di Wuhan.1 Tanggal 18 Desember hingga 29 Desember 2019, terdapat lima pasien yang dirawat dengan Acute Respiratory Distress Syndrome (ARDS).2 Sejak 31 Desember 2019 hingga 3 Januari 2020 kasus ini meningkat pesat, ditandai dengan dilaporkannya sebanyak 44 kasus. Tidak sampai satu bulan, penyakit ini telah menyebar di berbagai provinsi lain di China, Thailand, Jepang, dan Korea Selatan.
Sampel yang diteliti menunjukkan etiologi coronavirus baru. Awalnya, penyakit ini dinamakan sementara sebagai 2019 novel coronavirus (2019-nCoV), kemudian WHO mengumumkan nama baru pada 11 Februari 2020 yaitu Coronavirus Disease (COVID-19) yang disebabkan oleh virus Severe Acute Respiratory Syndrome Coronavirus-2 (SARS-CoV-2).4 Virus ini dapat ditularkan dari manusia ke manusia dan telah menyebar secara luas di China dan lebih dari 190 negara dan teritori lainnya.5 Pada 12 Maret 2020, WHO mengumumkan COVID-19 sebagai pandemik.6 Hingga tanggal 29 Maret 2020, terdapat 634.835 kasus dan 33.106 jumlah kematian di seluruh dunia.5 
Sementara di Indonesia sudah ditetapkan 1.528 kasus dengan positif COVID-19 dan 136 kasus kematian.

COVID-19 pertama dilaporkan di Indonesia pada tanggal 2 Maret 2020 sejumlah dua kasus.9 Data 31 Maret 2020 menunjukkan kasus yang terkonfirmasi berjumlah 1.528 kasus dan 136 kasus kematian.10 Tingkat mortalitas COVID-19 di Indonesia sebesar 8,9\%, angka ini merupakan yang tertinggi di Asia Tenggara.5,11 Per 30 Maret 2020, terdapat 693.224 kasus dan 33.106 kematian di seluruh dunia. Eropa dan Amerika Utara telah menjadi pusat pandemi COVID-19, dengan kasus dan kematian sudah melampaui China. Amerika Serikat menduduki peringkat pertama dengan kasus COVID-19 terbanyak dengan penambahan kasus baru sebanyak 19.332 kasus pada tanggal 30 Maret 2020 disusul oleh Spanyol dengan 6.549 kasus baru. Italia memiliki tingkat mortalitas paling tinggi di dunia, yaitu 11,3\%.5.

Di tengah merebaknya penyakit Korona yang melanda negeri kita tercinta dan dunia, keluarga sebagai unit terkecil dalam masyarakat yang terdiri dari suami istri, atau suami, istri dan anaknya, atau ayah dan anaknya, atau ibu dan anaknya, tentu memiliki peran penting dalam mencegah penyakit yang disebabkan oleh Corona Virus Disease 2019 (Covid-19). Hal ini mengingat lingkungan keluarga merupakan lingkungan yang pertama bagi anak dan lingkungan utama bagi seluruh anggota keluarga. Lebih dari itu, keluarga menjadi tempat berkumpul, berdiskusi, saling berbagi dan bersosialisasi bagi seluruh anggotanya. Bahkan karena diikat oleh perkawinan yang sah, seluruh anggota keluarga memiliki kedekatan jiwa yang sangat kuat. Apalagi anak-anak mereka yang memiliki hubungan darah.

Dengan upaya yang sungguhungguh dari seluruh keluarga di Indonesia dalam pencegahan Covid-19 sebagai penyebab utama penyakit Korona ini, yang dibarengi dengan seriusnya upaya pemerintah dalam memeranginya, kita dapat menyakini hasilnya akan cepat terlihat dalam bentuk terkendalinya penyebaran penyakit ini serta dapat dibasminya penyakit tersebut sampai ke akar-akarnya. Pada akhirnya seluruh keluarga, masyarakat, bangsa dan negara kita akan dapat kembali meraih kehidupan yang aman, tenteram dan sejahtera.

\section{METODE}

Metode yang digunakan dalam penelitian ini adalah studi kepustakaan, yaitu studi yang objek penelitiannya berupa karyakarya kepustakaan baik berupa jurnal ilmiah, buku, artikel dalam media massa, maupun data-data statistika. Dan dengan kepustakaan tersebut dapat ditemukan bahwa keluarga berperan dalam 
meningkatkan keselamatan dan pencegahan penularan covid-19.

\section{HASIL}

Peran keluarga dalam mencegah Covid-19 setidaknya mencakup empat hal: Pertama, menanamkan pola pikir yang benar tentang penyakit Korona dengan memberikan informasi yang tepat dan selengkap-lengkapnya tentang penyakit ini mulai dari faktor penyebab, cara penularan, persebaran terkini, cara pencegahan, resiko bagi yang terinfeksi, hingga upaya penanganan bila ada anggota keluarga yang terinfeksi

Kedua, menanamkan sikap yang benar dalam menghadapi penyakit Korona yang memang tidak bisa diremehkan dampaknya bagi keluarga, masyarakat, bangsa dan negara. Sikap yang dimaksud adalah tetap sabar dan tawakal bahwa penyakit ini adalah cobaan dari Allah Tuhan Yang Maha Esa, sehingga tidak ada anggota keluarga yang mengeluh, saling menyalahkan atau menghujat orang lain/pemerintah karena dianggap tidak becus menangani penyakit ini.

Ketiga, mengajarkan perilaku yang benar untuk mencegah terjangkitnya anggota keluarga terhadap penyakit Korona. Perilaku yang benar ini diantaranya adalah dengan menjalankan perilaku hidup yang bersih dan sehat untuk meningkatkan daya tahan tubuh sehingga terhindar dari berbagai penyakit termasuk Korona.

Keempat, mengajak pada seluruh anggota keluarga untuk menjalankan 8 fungsi keluarga secara bersungguh-sungguh agar penyakit Korona lebih cepat dapat diatasi. Mulai dari fungsi keagamaan, sosial budaya, cinta kasih, perlindungan, sosialisasi dan Pendidikan, ekonomi hingga pembinaan lingkungan. Penerapan 8 fungsi ini setidaknya, mengajak seluruh anggota keluarga untuk rajin beribadah sesuai agama dan kepercayaannya masingmasing dan berdoa agar penyakit Korona segera dihilangkan dari muka bumi, bergotong royong membantu meringankan beban anggota keluarga yang sedang dirudung masalah, serta memberikan perhatian dan kasih sayang yang cukup kepada sesama anggota keluarga.

\section{PEMBAHASAN}

Pada awal tahun 2020 ini dunia dikejutkan dengan wabah virus corona (Covid-19) yang menginfeksi hampir seluruh negara di dunia. WHO Semenjak Januari 2020 telah menyatakan dunia masuk kedalam darurat global terkait virus ini2. Ini merupakan fenomena luar biasa yang terjadi di bumi pada abad ke 21, yang skalanya mungkin dapat disamakan dengan Perang Dunia II, karena event even skala besar (pertandingapertandingan olahraga internasional contohnya) hampir 
seluruhnya ditunda bahkan dibatalkan. Kondisi ini pernah terjadi hanya pada saat terjadi perang dunia saja, tidak pernah ada situasi lainnya yang dapat membatalkan acara-acara tersebut. Terhitung mulai tanggal 19 Maret 2020 sebanyak 214.894 orang terinfeksi virus corona, 8.732 orang meninggal dunia dan pasien yang telah sembuh sebanyak 83.313 orang.

Sampel yang diteliti menunjukkan etiologi coronavirus baru. Awalnya, penyakit ini dinamakan sementara sebagai 2019 novel coronavirus (2019-nCoV), kemudian WHO mengumumkan nama baru pada 11 Februari 2020 yaitu Coronavirus Disease (COVID-19) yang disebabkan oleh virus Severe Acute Respiratory Syndrome Coronavirus-2 (SARS-CoV-2).4 Virus ini dapat ditularkan dari manusia ke manusia dan telah menyebar secara luas di China dan lebih dari 190 negara dan teritori lainnya.5 Pada 12 Maret 2020, WHO mengumumkan COVID-19 sebagai pandemik.6 Hingga tanggal 29 Maret 2020, terdapat 634.835 kasus dan 33.106 jumlah kematian di seluruh dunia.5 Sementara di Indonesia sudah ditetapkan 1.528 kasus dengan positif COVID-19 dan 136 kasus kematian.

COVID-19 pertama dilaporkan di Indonesia pada tanggal 2 Maret 2020 sejumlah dua kasus.9 Data 31 Maret 2020 menunjukkan kasus yang terkonfirmasi berjumlah 1.528 kasus dan 136 kasus kematian.10 Tingkat mortalitas COVID-19 di Indonesia sebesar 8,9\%, angka ini merupakan yang tertinggi di Asia Tenggara.5,11 Per 30 Maret 2020, terdapat 693.224 kasus dan 33.106 kematian di seluruh dunia. Eropa dan Amerika Utara telah menjadi pusat pandemi COVID-19, dengan kasus dan kematian sudah melampaui China. Amerika Serikat menduduki peringkat pertama dengan kasus COVID-19 terbanyak dengan penambahan kasus baru sebanyak 19.332 kasus pada tanggal 30 Maret 2020 disusul oleh Spanyol dengan 6.549 kasus baru. Italia memiliki tingkat mortalitas paling tinggi di dunia, yaitu 11,3\%.5.

Keluarga merupakan bagian dari tim pengobatan dan perawatan yang paling dekat. Apalagi di Indonesia dengan kultur sosialnya tinggi ditambah keterbatasan jumlah perawat sehingga tugas merawat orang sakit sering dilakukan oleh keluarga pasien. Maka dari itu keluaga perlu diberikan penkes mengenai keselamatan pasien sehingga saat dirumah maupun dirumah sakit pasien dapat terhindar akan bahaya maupun adverse moment.

Di tengah merebaknya penyakit Korona yang melanda negeri kita tercinta dan dunia, keluarga sebagai unit terkecil dalam masyarakat yang terdiri dari suami 
istri, atau suami, istri dan anaknya, atau ayah dan anaknya, atau ibu dan anaknya, tentu memiliki peran penting dalam mencegah penyakit yang disebabkan oleh Corona Virus Disease 2019 (Covid-19). Hal ini mengingat lingkungan keluarga merupakan lingkungan yang pertama bagi anak dan lingkungan utama bagi seluruh anggota keluarga. Lebih dari itu, keluarga menjadi tempat berkumpul, berdiskusi, saling berbagi dan bersosialisasi bagi seluruh anggotanya. Bahkan karena diikat oleh perkawinan yang sah, seluruh anggota keluarga memiliki kedekatan jiwa yang sangat kuat. Apalagi anak-anak mereka yang memiliki hubungan darah.

Peran penting keluarga dalam pencegahan penyakit Korona ini semakin menguat, saat pemerintah menganjurkan warganya banyak tinggal di rumah sebagai bagian dari upaya mencegah meluasnya penyakit ini agar lebih mudah mengatasinya. Termasuk penerapan belajar secara online maupun offline yang berlaku bagi siswa SD hingga SMA sederajat dan mahasiswa Perguruan Tinggi. Dengan demikian, keluarga memiliki kewajiban/tanggung jawab yang Besar untuk mengkondisikan lingkungannya agar dapat memproteksi penyakit yang telah banyak menelan korban jiwa itu.

Peran keluarga dalam mencegah Covid-19 setidaknya mencakup empat hal: Pertama, menanamkan pola pikir yang benar tentang penyakit Korona dengan memberikan informasi yang tepat dan selengkap-lengkapnya tentang penyakit ini mulai dari faktor penyebab, cara penularan, persebaran terkini, cara pencegahan, resiko bagi yang terinfeksi, hingga upaya penanganan bila ada anggota keluarga yang terinfeksi. Dengan pemberian pengetahuan yang cukup, akan membuat ketenangan jiwa seluruh anggota keluarga tanpa meninggalkan kewaspadaan terhadap bahaya penyakit ini.

Kedua, menanamkan sikap yang benar dalam menghadapi penyakit Korona yang memang tidak bisa diremehkan dampaknya bagi keluarga, masyarakat, bangsa dan negara. Sikap yang dimaksud adalah tetap sabar dan tawakal bahwa penyakit ini adalah cobaan dari Allah Tuhan Yang Maha Esa, sehingga tidak ada anggota keluarga yang mengeluh, saling menyalahkan atau menghujat orang lain/pemerintah karena dianggap tidak becus menangani penyakit ini. Sikap yang benar ini juga perlu ditunjukkan dengan sikap disiplin dan patuh terhadap peraturan yang diberlakukan oleh pemerintah sehingga memudahkan dalam pengendalian penyakit Korona yang telah merambah seluruh bangsa di dunia ini.

Ketiga, mengajarkan perilaku yang benar untuk mencegah terjangkitnya 
anggota keluarga terhadap penyakit Korona. Perilaku yang benar ini diantaranya adalah dengan menjalankan perilaku hidup yang bersih dan sehat untuk meningkatkan daya tahan tubuh sehingga terhindar dari berbagai penyakit termasuk Korona. Implementasinya, selalu menjaga kebersihan diri dan lingkungannya, selalu cuci tangan saat akan dan sesudah melakukan sesuatu, rajin berolah raga, makan makanan dengan menu gizi seimbang, menerapkan cara bergaul yang sehat, menggunakan masker atau sarung tangan saat pergi keluar rumah, menggunakan pakaian yang dapat melindungi tubuh apabila bersentuhan dengan orang lain tanpa sengaja, dan sebagainya.

Keempat, mengajak pada seluruh anggota keluarga untuk menjalankan 8 fungsi keluarga secara bersungguhsungguh agar penyakit Korona lebih cepat dapat diatasi. Mulai dari fungsi keagamaan, sosial budaya, cinta kasih, perlindungan, sosialisasi dan Pendidikan, ekonomi hingga pembinaan lingkungan. Penerapan 8 fungsi ini setidaknya, mengajak seluruh anggota keluarga untuk rajin beribadah sesuai agama dan kepercayaannya masing-masing dan berdoa agar penyakit Korona segera dihilangkan dari muka bumi, bergotong royong membantu meringankan beban anggota keluarga yang sedang dirudung masalah, serta memberikan perhatian dan kasih sayang yang cukup kepada sesama anggota keluarga. Selain itu memberikan rasa aman dan tenteram satu sama lain, menolong anggota keluarga yang dalam kesulitan serta menjaga keharmonisan hubungan antara anggota keluarga. Tidak boleh dilupakan menjaga kebersihan rumah dan lingkungan serta menjaga hubungan baik dan peduli dengan tetangga dan masyarakat sekitar.

Peran penting keluarga dalam pencegahan penyakit Korona ini tentu saja akan dapat dilakukan secara baik manakala Ayah dan atau Ibu mampu berposisi sebagai motor penggerak dan pemberi motivasi. Ayah dan Ibu (baca: pasangan Suami Isteri), Ayah atau Ibu di mata anggota keluarga yang lain (baca: anak) adalah orang-orang yang diteladani dan dijadikan figur. Oleh karena itu, ayah dan atau ibu harus mampu memberikan contoh yang baik dalam pencegahan penyakit Korona dalam lingkungan keluarga. Mulai dari rajin ibadah dan berdoa, menjaga kebersihan, rajin berolah raga, makanmakanan yang bergizi dengan menu seimbang, bersikap dan berperilaku yang tidak beresiko saat bertemu dengan orang lain hingga taat dan patuh terhadap anjuran atau kebijakan pemerintah dalam memerangi wabah Korona ini.

Dengan upaya yang sungguhungguh dari seluruh keluarga di Indonesia 
dalam pencegahan Covid-19 sebagai penyebab utama penyakit Korona ini, yang dibarengi dengan seriusnya upaya pemerintah dalam memeranginya, kita dapat menyakini hasilnya akan cepat terlihat dalam bentuk terkendalinya penyebaran penyakit ini serta dapat dibasminya penyakit tersebut sampai ke akar-akarnya. Pada akhirnya seluruh keluarga, masyarakat, bangsa dan negara kita akan dapat kembali meraih kehidupan yang aman, tenteram dan sejahtera.

Sehingga diharapkan dengan bantuan dan kesadaran setiap keluarga maka akan mempersempit penularan. Begitupun dengan keluarga yang memiliki anggota keluarga yang merupakan pasien positif covid maka dapat melakukan isolasi mandiri maupun langsung ke layanan kesehatan untuk mencegah terjadinya penularan di sekitar tempat tinggal.

\section{PENUTUP}

Pandemi covid-19 merupakan kejadian yang luarbiasa yang banyak memakan korban dari seluruh dunia. Ada berbagai cara yang bisa kita lakukan untuk memperkecil ruang lingkup penularan covid-19. Hal paling sederhana namun sangat berdampak besar adalah dengan berperan aktifnya keluarga. Hal ini mengingat lingkungan keluarga merupakan lingkungan yang pertama bagi anak dan lingkungan utama bagi seluruh anggota keluarga. Lebih dari itu, keluarga menjadi tempat berkumpul, berdiskusi, saling berbagi dan bersosialisasi bagi seluruh anggotanya.

\section{DAFTAR PUSTAKA}

Aditya Susilo, Dkk.( 2019). Corona Virus Disease : Tinjauan Literatur Terkini. Jurnal Penyakit Dalam Indonesia. Vol 7, No 1, Maret 2020

Dana Riksa. (2020). Analisis Perilaku Mayarakat Indonesia dalam Menghadapi Pandemi Virus Corona (covid-19) dan Kiat menjaga Kesejahteraan Jiwa. SALAM Jurnal Sosial dan Budaya Syar'I.

Diah Handayani,dkk. (2020). Penyakit Virus Corona 2019. Jurnal Respirologi Indonesia. Vol. 40, No. 2, April 2020.

Direktorat Jenderal Pencegahan dan Pengendalian Penyakit (P2P) Kementerian Kesehatan RI. Pedoman Kesiapsiagaan Menghadapi Infeksi Novel Coronavirus (2019-nCoV). Available from:

https://covid19.kemkes.go.id/downloads/\#. Xtva cited : 2020 October 2

Ganjar Prabowo.(2020). Peran Keluarga untuk Cegah Covid Sangat Diperlukan. Health Magazine April 2020 
Kementerian Kesehatan Republik

Indonesia. Info Infeksi Emerging

Kementerian Kesehatan RI [Internet].

2020 [updated 2020 March 30; cited 2020

October2].Available from :

https://infeksiemerging.kemkes.go.id/.

Mardiya (2020). Peran Keluarga Cegah

Covid-19. Admin Pemberdaya Online

Magazine 31 Maret 2020

Simamora, R. H. (2019). Buku Ajar Pelaksanaan Identifikasi Pasien. Uwais Inspirasi Indonesia

Syafrida. (2020). Bersama Melawan Virus Covi-19 di Indonesia. SALAM Jurnal Sosial dan Budaya Syar-i. Vol 7, No.6 2020

Wahyu Dwi Nugroho. (2020). Transmisi Covid-19 Dari Manusia ke Manusia di Asia. Journal of Bionursing. Vol. 2, No.2, 101-102.

Yuliana .(2020).Cororna Virus Disease (covid-19). Wellnes and Healthy Magazine. Vol 2 no 1,February 2020 ISSN 2656-0062 